\title{
A New Conceptualization and Measurement of Corporate Identity: \\ Evidence from the UK Food and Beverage Industry
}

\begin{abstract}
This study extends the conceptualization of corporate identity (CI), and develops a valid and reliable scale for the concept via multistage research design. After detailed literature review, key elements of CI in practice are clarified using 20 semi-structured interviews with senior managers in leading UK companies, followed by an online survey among senior managers in the UK food and beverage sector. Five dimensions of CI are identified following two-step structural equation modelling: consistent image, top management behavioral leadership, employee identification, mission and values dissemination, and founder transformational leadership. The scale is examined for nomological validity with an outcome variable, namely corporate social responsibility. The contribution is novel, as for the first time CI is empirically validated as a second-order hierarchical construct. The resultant scale guides practitioners to specify priorities when developing CI, acts as a tool to assess the effectiveness of activities over time, and enables corrective action where needed.
\end{abstract}

Keywords Corporate identity, Communication, Visual identity, Employee identification, Leadership 


\section{Introduction}

Via a multidisciplinary approach, this paper is aimed to to improve understanding of corporate identity $(\mathrm{CI})$ by providing theoretical clarification of the concept's key dimensions and a measurement scale that demonstrates a high degree of reliability and validity. The aim is timely, given the increasing interest of scholars and practitioners (Gambetti et al., 2017) in $\mathrm{CI}$ as an intangible asset that is considered to be an effective strategic instrument and a route to competitive advantage (Balmer, 2017). CI, encompassing values, behavior and communication, has become a key element of differentiation strategies, affecting not only image and reputation but also financial performance (Bravo et al., 2016).

Although many conceptual studies have addressed CI's theoretical foundations, resulting in different taxonomies and schools of thought which help structure the concept, they also overlap, thus obfuscating boundaries. Developed frameworks are too disperse (i.e. Balmer, 1995) or lack theoretical rigour (Cornelissen et al., 2012). This ambivalence renders practical operationalization of the construct challenging, and reveals the need for valid, reliable and parsimonious CI scales that could empirically reveal construct dimensionality and/or its relationship to other concepts (Kitchen et al., 2013). This lack of consensuality is also reflected in the business world. While executives consider CI to be very important, many admit to having little knowledge of how to manage, control or even explicitly define it (Melewar and Karaosmanoglu, 2006). Until its key properties are identified and operationalized, the concept will remain underdeveloped. It is insufficient to advise practitioners that $\mathrm{CI}$ is key to successful brand distinctiveness without explaining what constitutes it.

In this paper, therefore, we aim to clearly identify and fully validate a comprehensive CI measurement scale. To achieve this, the study follows Churchill's (1979) scale development 
paradigm, firstly by exploring the concept using 20 semi-structured interviews with senior managers in leading UK companies to gain an in-depth understanding of the meaning and key elements of CI. This is followed by an online survey of senior managers in the UK food and beverage sector. Data analysis involves exploratory factor analysis (EFA) and confirmatory factor analysis (CFA) to ensure the scale's psychometric properties and measurement validation process, and concludes with full structural equation modelling (SEM) to test the conceptual model's nomological validity. Upon validation confirmation, the study performs nomological validity with a consequence variable, namely corporate social responsibility (CSR). This decision is based on the premise that CI could provide the catalyst and optimal platform for developing and implementing CSR in congruence with what the company stands for (Tourky et al., 2019). In today's climate, which places CSR and ethics firmly on sociopolitical and business agendas, the concept of CI seems largely a manifestation of CSR, reflecting companies' ethical stances and behavior (Cornelius et al., 2007). Consequently, CI, CSR and ethical behavior receive significant attention in the literature and public media (Powell, 2011).

This study offers three main contributions. Firstly, it enhances the CI measurement scale by considering a range of elements not previously empirically measured, such as top management behavioral leadership, employee identification and founder transformational leadership, creating an eclectic, comprehensive measurement applicable in a non-service context. Secondly, this scale, unprecedentedly, conforms to a second-order factor model (that ties CI to five distinct primary dimensions) which have proved to be successful in increasing theoretical parsimony and reducing model complexity (MacKenzie et al., 2005; Wetzels et al., 2009), thus allowing an assessment of the construct's holistic influence on a range of endogenous variables such as corporate image, reputation, financial performance, etc. Thirdly, beside its academic value, the scale is useful to practitioners, who can use it as a checklist to 
specify priorities in developing CI, and as a tool to assess the effectiveness of activities over time, and to take corrective action when needed.

\section{Literature review}

\subsection{The meaning of $C I$}

The meaning of CI is still debated (Kitchen et al., 2013) as definitions evolve from partial views to an interdisciplinary approach (see Appendix 1). Early research sought to define corporate visual identity (CVI) (e.g. Abratt, 1989), but the meaning of CI now extends to incorporate the intrinsic characteristics experienced through everything an organization says, makes or does (Balmer, 2001, 2017). From an organizational behavior perspective, Hatch and Schultz (1997) acknowledge that organizational culture tends to nurture local meanings and organizational symbols (Balmer, 2017). Other scholars (i.e. Van Rekom, 1997) relate CI to external audiences from a marketing and communication standpoint, and regard this as central to organizational communication. Bringing together these perspectives, Van Riel and Balmer (1997) propose that communication, behavior and symbolism all serve as means for a company to make itself known (Schmeltz, 2014).

In a similar vein, Melewar (2003) and his co-authors (Melewar and Karaosmanoglu, 2006; Melewar et al., 2005; Melewar et al., 2018), via a multidisciplinary approach, broadened the meaning to include the unique mix of elements that differentiates organizations. Melewar's (2003) model comes closest to operationalizing CI through its guidance for defining the construct and specifying its domain. These studies developed and structured the nascent literature but necessitate empirical support.

Despite a number of frameworks to capture the construct (e.g. Balmer 1995, 1997, 1998) and Balmer and Soenen's (1999) ACID test, they drew some criticism (Alessandri, 2001; Cornelissen et al., 2012) as overlapping and contiguous interconnections persist which obfuscate CI boundaries. Besides, the wide range of dimensions and elements with differing 
emphases in CI challenge attempts to achieve unanimity on what constitutes this construct, particularly on classifying its components (Cornelissen et al., 2012; Bravo et al., 2016), resulting in a shortage of empirical research to develop valid, reliable and parsimonious CI scales which could serve via empirical testing to reveal construct dimensionality.

Notably, the only extant CI scale (that of Simões et al., 2005) considers only the internal controlled perspective of CI, measures three internal elements, and was tested only in the UK hotel industry. This paper hence addresses both conceptual and measurement issues in studying CI and its impact on corporate marketing [i.e. CSR] by extending the number of dimensions of the CI scale relative to a discrete segment of manufacturing industry.

\subsection{Theoretical perspectives of $C I$}

Different theoretical perspectives underpinning CI are cited in the literature, including the visual/graphic design, communication, organizational and interdisciplinary perspectives (Simões et al., 2005).

The visual/graphic design perspective pertains to corporate symbols (e.g., names and symbols, logos, typefaces, color schemes, etc) that convey the strategic, visual dimensions of CI (Van Riel and Balmer, 1997; Bravo et al., 2016). Visual cues can convey corporate strategy, present the organization's central idea (Olins, 1995: 2), and allow its recognition among audiences and distinction from other companies (Bernstein, 1984; Melewar and Karaosmanoglu, 2006). Consistency is required (Simões et al., 2005), and some researchers have considered the need for multinational businesses to standardize the visual aspects of their global corporate identity (Melewar and Saunders, 2000).

The communication perspective ... pertains to all types of internal and external communication, which should be consistently conveyed to build satisfactory relationships with stakeholders (Van Riel, 1995; Van Rekom, 1997). Externally, corporate communication can convey distinct $\mathrm{CI}$ and position products and services, which can generate favourable 
stakeholder attitudes and positive CI, underpin purchase intent (David et al., 2005), and enhance corporate image, reputation and revenue. Given the salience of the internal environment and the role of employees in conveying organizational identity (OI) (i.e., what an organization is) and corporate image formation (i.e., how an organization is perceived), internal communications are also vital in forming CI.

Further, gaining a competitive advantage from brand messages requires the integration of internal and external communications. Integrated communications strategies create synergies among different forms of communication and encourage consistency throughout an organization, despite unwillingness to invest corporate resources.

The organizational studies perspective ... relates to internal aspects of identity, emphasising meaning, emotion and human aspects (Ashforth, and Dutton, 2000). Organizational identity (OI) has been described as the central, enduring and distinctive nature of an organization (Albert and Whetten, 1985), a form of social identification where people feel they "belong" to an organization (Punjaisri et al., 2009) which can lead to expressions of the affective, evaluative and behavioral aspects of identification (Riketta, 2005). Employee identification with an organization (i.e., the degree to which members define themselves by the same attributes as those they believe define the organization) is considered a measure of employee behavior (Van Riel and Fombrun, 2007). Employee alignment with corporate principles and objectives may improve customer interactions (Kitchen et al., 2013) and competitive advantage (Boroş, 2008).

The organizational literature also stresses senior management's role in promoting attractive organizational images to stakeholders (Balmer, 2017), building organizational identification (Hill and Jones, 1992) and fulfilling other strategic purposes such as corporate reputationbuilding and goal attainment; engaging in representational leadership, which can be both positive and negative (Kitchen et al., 2013). 
The important role of founders or value-based leaders in developing and mobilizing CI has also been outlined in the organizational literature. Transformational leadership best creates identification (Bass, 1990), since "leader" behaviors influence value systems and employee aspirations, and may encourage self-sacrifice "for the sake of the [corporate] brand" (Burmann and Zeplin, 2005: 293). Although founder importance is commonly historical, stated principles often linger in OI (Haski-Leventhal et al., 2017). Thus, the founding stage is often critical to identity formation beyond the founder's presence (Balmer, 2017).

The interdisciplinary perspective ... harmonizes graphic design, communication and organizational studies. Van Riel and Balmer (1997: 341) note that CI refers to "the way(s) in which an organization's identity is revealed" through behavior, communications and symbolism. Melewar et al. (2005) also acknowledge CI as a broad, multidisciplinary concept representing the sum of all factors that define and project "what the organization is", "what it stands for", "what it does", "how it does it" and "where it is going" (Melewar and Karaosmanoglu, 2006). This paved the way for an interrogative-based line of thinking (i.e. Melewar and Jenkins, 2002; Melewar et al., 2005; Melewar et al., 2018). However, since CI is eclectic, grounding analysis in one field provides only a partial view.

This study therefore adopts an interdisciplinary approach and an overarching view (Abratt and Mingione, 2017), proposing that CI reflects six dimensions: communication, CVI, top management, employee behaviour, mission and values, and founder leadership. In addition, it considers $\mathrm{CI}$ as a strategic concept and as a managerial rather than a consumer construct.

We now discuss these dimensions.

\subsection{Dimensions of $C I$}

Communication. Most CI scholars note the key role of communication in building CI (Cornelissen et al., 2012; Balmer, 2017). Communication includes both marketing communications (e.g. on- and offline advertising, sales promotion, direct marketing and 
sponsorship) and corporate communications (public relations [PR], investor and labour relations, house journals and magazines for internal staff, and environmental and annual reports for external stakeholders). Coherence among these tools is vital for conveying consistent messages and a unified image. Accordingly, this study conceptualizes communication in terms of breadth and consistency across media and messages.

CVI. CVI refers to the collection of visual expressions through which stakeholders can identify a corporation and differentiate it from others (Foroudi et al., 2014). At the design level, CVI emphasises the functionality and effectiveness of specific elements of visual identity, treated as a means to an end. Elements of CVI include: (1) corporate visual identity system (CVIS), covering aspects such as logo/symbol, name, slogan, colour and typography (Melewar and Saunders, 2000); and (2) applications of the CVIS, such as corporate aesthetics (e.g. stationery, promotional literature) and the exterior and interior design of company buildings (Van den Bosch et al., 2006). At the operational level, CVI focuses on translating a desired CI into a consistent visual self-presentation (Melewar and Saunders, 2000), where consistency is defined as "the extent to which the various CVI elements were actually employed as intended" (Van den Bosch et al., 2006: 873). This is based on the development of CVI guidelines and the way they are applied, resulting in a more or less consistent visual expression. This study conceptualizes CVI in terms of the functionality and application of CVIS to convey what the company stands for and the accompanying consistency.

Top management. Top management representational behavior includes the words and behavior of senior managers, i.e. the way they operate, which can be important to CI in influencing stakeholder perceptions (Scott and Lane, 2000; Melewar, 2003; Kitchen et al., 2013). Van Riel (1995) argues that CEOs play important symbolic roles as organizational leaders and are occasionally ascribed with almost heroic characteristics (Vallaster and De Chernatony, 2006). They also contribute to PR activities and may act as spokespersons. 
Therefore, behavioral leadership informs the conceptualization of top management, centering on top managers' role as organizational representatives, which is not always positive.

Employee behavior. CI characteristics are rooted in employee behavior (Balmer, 2017), including the attitudes and everyday behavior of organizational staff (Hatch and Schultz, 1997) and relating to OI. From an organizational perspective, we agree that employees' identification with an organization prefigures their behavior (Van Riel and Fombrun, 2007). The more that employees identify with an organization, the more likely they are to accept organizational premises (not necessarily 'promises'), hold supportive attitudes, and uphold organizational actions and identity.

Mission and values. The mission statement reveals an organization's stated purpose over time (Balmer, 2017); thus, explicitly or implicitly, it conveys organizational identity. Mission statements articulate corporate goals, values and philosophy, highlighting uniqueness and determining direction (Van Riel and Balmer, 1997; Balmer, 2017). The organization's mission helps establish behavioral guidelines for employees, so it must be properly communicated to and interpreted by employees (Kitchen et al., 2013). We therefore look to mission and values dissemination to conceptualize this dimension.

Founder. Business founders are referred to as value-based leaders who set organizational vision and shape CI through their impact on organizational culture, especially in initial small- and medium-sized businesses (Brexendorf and Kernstock, 2007). They invoke moral justifications, meaning and ways for followers to identify with corporate goals (Christensen et al., 2014). Therefore, we consider the founder from the leadership perspective, and conceptualize such leadership as the provision of meaning to followers, advancing corporate goals and solving problems (Bass, 1990; Shamir et al., 1993).

We now turn to CI scale development 


\section{CI scale development}

To develop a theoretically sound conceptualization of CI and a valid measurement scale, we consulted the scaling literature (Churchill, 1979; DeVellis, 1991; Anderson and Gerbing, 1988) (see Figure 1). Accordingly, the following sections report on CI's conceptual domain specification, item generation, scale purification, scale validation, nomological validity assessment and scale norm development.

\section{Insert Figure 1 here}

\subsection{Conceptual domain specification}

The first step of scale development involved exploring the nature and meaning of CI (Churchill, 1979) and gaining an in-depth understanding of the elements of the CI mix and the factors supporting CI development and implementation. This was achieved by means of a comprehensive literature review and by drawing upon empirical evidence from 20 semistructured interviews with senior managers responsible for marshalling the CI mix and CSR from 10 leading UK-based companies, two from each compay, in addition to three interviews with advertising and branding agency executives who worked closely with these firms in cognate areas. Further information provided by informants or obtained by the researchers was examined, including secondary data such as websites and published documents, covering areas such as corporate aims, vision, mission and values. This was important owing to the vague or partial definitions of $\mathrm{CI}$ and the uncertainty and disagreement in the literature on what constitutes the domain of the concept. The qualitative research findings, analysed using Nvivo 9, provided primary information for the salient elements of CI from a practitioner's perspective and guidelines for conceptualizing and measuring items on the CI scale.

The qualitative findings, supported by previous contributions to $\mathrm{CI}$, show strong agreement among interviewees that CI reflects six salient dimensions: communication (Van Riel, 1995; Schmeltz, 2014); CVI (Carter, 1982; Melewar and Saunders, 2000; Dowling, 
2001; Van den Bosch et al., 2006, Foroudi et al., 2014); top management behavioral leadership (Balmer, 2017; Conte et al., 2017); employee identification (Van Riel and Fombrun, 2007; Kitchen et al., 2013); mission and value dissemination (Simões et al., 2005; Simões and Sebastiani, 2017); and founder transformational leadership (Brexendorf and Kernstock, 2007; Hillestad et al., 2010; Christensen et al., 2014; Balmer, 2017). This confirms a multidimensional construct and supports our theoretical position of examining CI from a multidisciplinary perspective that includes marketing (communications), visual identity (graphic design), organizational studies (organization identity and behavioral and transformational leadership).

\subsection{Item generation, and content and face validity}

After defining CI and a priori postulating its dimensionality, it was necessary to generate a pool of items that captured the conceptual domain, and to scale each dimension for the experience survey (Churchill, 1979). Consistent with the scaling literature, multiple items were developed for each dimension. Table 1 provides details of the literature used to scale each dimension.

\section{Insert Table 1 here}

The experience survey was used to ask an expert panel how far each item represented the domain of CI using a three-point Likert scale $(1=$ clearly representative, $2=$ somewhat representative, and $3=$ not at all representative) (Zaichkowsky, 1985). Panel members were also invited to suggest new items to enhance content validity. Pre-tests followed to reach the final survey. Finally, to identify any remaining inconsistencies, we conducted a pilot study among 10 marketing managers in food companies selected randomly from the sampling frame; these respondents suggested no further improvements. 


\subsection{Sampling and data collection}

The target population was UK food and beverage organizations. These provide a highly relevant market representing more than $15 \%$ of manufacturing turnover and employment. This sector is a core element of the UK manufacturing economy (Food and Drink Federation, 2017). Importantly, through the recent recession, it was the least volatile sector and the strongest in terms of economic recovery (Institute for Manufacturing [IfM], 2010). Moreover, since 1990, UK food and beverage manufacturing has reduced its $\mathrm{CO}_{2}$ emissions by at least $11 \%$ (ibid.), showing a strong effort in relation to the environmental impact of food production, which reflects a commitment to CSR. As Clark (2006) states, the food and beverage sector has been particularly successful in developing brands with a strong identity concerned with ethics and CSR, usually by emphasizing the quality and provenance of products. Thus, this sector should gain a strategic focus of public and private action in order to remain a high-value sector with significant social and environmental impacts (IfM, 2010).

The sampling frame consisted of 824 senior marketing executives from this sector, drawn from the One Source database at the British Library (Coleman et al., 2011). If contact details for nominated executives were not shown, the communication manager/CEO/general manager or managing director was selected, reckoning that CI demands strategic activity and that such executives would be well placed to comment on it (He, 2012).

All 824 executives received the final questionnaire. Having contacted each company by telephone, we sent executive managers e-mails that asked them to complete the survey and included a link to a website to the questionnaire for online completion, if convenient (Lloria and Moreno-Luzon, 2014). A total of 126 questionnaires was completed, representing a response rate of $15.3 \%$, which was sufficient for the purpose of this study.

The respondents' profiles revealed that more than half $(50.80 \%)$ were marketing managers/directors of a business unit, followed by general managers/directors $(18.30 \%)$; 
almost half (46.80\%) had held this rank for at least five years. This level of experience suggests they would have considerable knowledge of the industry and its activities. Most of the companies were operating in England (78.60\%). Food companies predominantly manufacture other food products (38.10\%; e.g. bread, biscuits, cakes, cocoa and sugar), while beverage companies predominantly produce alcoholic beverages $(15.10 \%)$; these represent the two largest categories. Most companies (78.60\%) had been established for more than 20 years, and approximately 57\% were small- or medium-sized enterprises, classified as those with 249 or fewer employees (European Commission, 2005). Most were operating nationally and internationally (78.60\%); and 46\% were operating as both B2B and B2C.

To determine whether non-response bias was present in the study after sending the questionnaires to 824 respondents, we compared early and late respondents along all the response items for each of the scales. The chi-square tests showed no significant differences between the early and late respondents in demographic characteristics. In addition, t-test results indicated no significant differences between early and late respondents in stakeholder orientation and performance measures. Thus, non-response bias did not seriously affect the study.

\subsection{Statistical analysis of scale}

To check a scale's psychometric properties, its conceptual dimensions should be established by empirically examining its main dimensions: in this case communication, CVI, top management behavioral leadership, employee identification, mission and values dissemination, and founder transformational leadership. This task was performed using exploratory factor analysis (EFA), while reliability analysis was measured by corrected itemto-total correlation (CITC) and Cronbach's alpha. Finally, confirmatory factor analysis (CFA) helped verify convergent, discriminant and nomological validity before testing of the scale's nomological validity. 
Reliability and EFA. This study first examined the CITC for each set of items (dimension) representing CI and then deleted those with a CITC below 0.30 (Zaichkowsky, 1985). The Cronbach's alphas for each subscale ranged from 0.83 to 0.92 , all exceeding the recommended 0.70 cutoff value (Nunnally, 1978). At this early stage, we removed four items, leaving 25 items considered suitable for EFA (Hair et al., 2010). We established the dataset's suitability for EFA through Bartlett's test of sphericity $\left(\chi^{2}=1748.55, \mathrm{p}<0.000\right.$, df $\left.=231\right)$ and the Kaiser-Meyer-Olkin test (0.87).

Next, we evaluated the remaining items using EFA (principal components analysis) with PROMAX (oblique), expecting the dimensions to correlate for theoretical reasons (Field, 2009). An iterative process eliminated items with a factor loading below 0.50 , high crossloadings above 0.40 and commonalities below 0.50 (Hair et al., 2010). Furthermore, we identified underlying factors by multiple decision rules (Conway and Huffcutt, 2003). Factors needed eigenvalues greater than 1, and we eliminated single-item factors, given the goal of developing multi-item measures (DeVellis, 1991). Guided by these criteria, the final factor analysis resulted in five factors, a 22-item solution, with eigenvalues exceeding 1, which accounted for $71.91 \%$ of the variance. Table 2 reports the results of the EFA and Cronbach's alpha.

\section{Insert Table 2 here}

We adjusted the factor labels to account for aggregated items and reflect the content of new factors emerging from the EFA. Factor 1 (consistent image) comprises items of consistent communication and visual identity that enhance corporate image. Factor 2 (top management behavioral leadership) symbolically represents organizations to the public. Factor 3 (employee identification) concerns employees' pride in, acknowledgement of and identification with corporate values. Factor 4 (mission and values dissemination) embodies companies' inner sense of purpose, diffused among staff. Factor 5 (founder transformational 
leadership) embodies the organization's founder-sustained attributes, earning respect, solving problems, and encouraging employees to revisit ideas and develop their strengths.

Step 1: CFA, first and second order. In order to validate the above scale, structural equation modelling (SEM) was implemented using AMOS 20 and the default methodmaximum likelihood. A Two-Step approach tested the measurement model's validity and reliability (using both first- and second-order levels on CI in Step 1 CFA), and nomological validity (the full structural model in Step 2), as proposed by Anderson and Gerbing (1988). Upon validation confirmation, the study performed nomological validity with a consequence variable, CSR.

All 22 items of the CI scale were subjected to CFA, the measurement model and results were purified to establish the construct validity and reliability of the items generated earlier. The measurement model showed a good fit (Hair et al., 2010); for example $\left(\chi^{2}{ }_{[284]}=374.41\right.$; $\mathrm{p}<.01 ; \chi^{2} / \mathrm{df}=1.31 ; \mathrm{GFI}=.82 ; \mathrm{IFI}=.95 ; \mathrm{TLI}=.95 ; \mathrm{CFI}=.95 ;$ and $\left.\mathrm{RMSEA}=.05\right)$.

At this stage, CI was represented by five dimensions: consistent image, top management behavioral leadership, employee identification, mission and values dissemination, and founder transformational leadership. We proceeded to test these dimensions in second-order form. In particular, since CI was expected from the a priori theoretical structure to be multidimensional (e.g. Melewar and Karaosmanoglu, 2006), we tested in second-order form to ensure a thorough investigation of the construct validity. This is important, particularly for a newly-published scale, as it deals with validation of the scale (Bagozzi and Heatherton, 1994; Hair et al., 2010). The second order result yielded an acceptable fit $\left(\chi^{2}{ }_{[204]}=254.87 ; \mathrm{p}\right.$ $<.01 ; \chi^{2} / \mathrm{df}=1.24 ; \mathrm{GFI}=.85 ; \mathrm{IFI}=.97 ; \mathrm{TLI}=.96 ; \mathrm{CFI}=.97 ;$ and $\left.\mathrm{RMSEA}=.04\right) . \mathrm{A}$ comparison of the first- and second-order model results showed that both performed similarly, with second order performing slightly better. Hence, a decision was made to select second-order for further analysis, based on: (1) the a priori theoretical status of both scales 
(Melewar, 2003; Melewar and Karaosmanoglu, 2006); and (2) statistical grounds (construct validity) - that is, when both models yield acceptable results they may be used for further analysis (Wolfinbarger and Gilly, 2003), but using second-order model permits a stronger statement. Thus, while some dimensions of CI overlap, they are to some extent distinct from each other (Hair et al., 2010).

Table 3 shows the structural relationships (or factor loadings) covaried from one dimension to another when they were tested in higher/second-order form, simultaneously supporting claims that CI could be explained by a multidimensional construct and that its dimensions vary with context. In particular, CI explains $60 \%, 79 \%, 77 \%, 67 \%$ and $57 \%$ of the variance associated with the dimensions: corporate image, top management behavioral leadership, employee identification, mission and values dissemination, and founder transformational leadership. The construct reliability tests using both composite reliability and Cronbach's alpha all scored above the recommended level. The correlation among the constructs is also acceptably low, ranging from .30 to .62 and AVE $=>.50$ (Fornell and Larcker, 1981, see Table 4). A further test to ensure adequate discriminant validity was performed by comparing all the AVE estimates with the square pairwise correlation between factors and cross-loadings examinations among the measured variables and error terms (Hair et al., 2010). Additionally, discriminant validity was confirmed for all latent constructs since the square root of each construct's AVE was greater than the bivariate correlation (see Table 4). At this stage, cross-loadings between both measured and error terms also did not suffer from substantial cross-loadings; standardized residuals were all $<2.58$ (Byrne, 2001). Convergent validity was supported, with all parameter estimates $>.5$ (Kline, 1998). Table 3 shows details of each CFA individual item's convergent validity and all items statistically significant at $\mathrm{p}<.01$ (Anderson and Gerbing, 1988). Thus, the assessment results supported the adequacy of the discriminant validity of the measurement model. Establishing these, we 
entered the next stage, the full measurement model, by performing all constructs that represented $\mathrm{CI}$ and CSR simultaneously in order to establish the construct validity (or the nomological validity) before, Step 2, the structural model was established. See Figure 2 for the final and full measurement model.

\section{Insert Table 3 here \\ Insert Table 4 here \\ Insert Figure 2 here}

Step 2: The full structural model - nomological validity. In Step 2, we assessed the nomological validity of the CI scale with one outcome variable, CSR. Theoretically, it was likely to consider likely a positive association between CI and CSR. According to Basu and Palazzo (2008), CSR-related activities align with an organization's inherent direction through a sensemaking process within which CSR is rooted. In this approach, activities such as CSR are not a direct result of external demands, but are founded on the orientation of CI and originate from organizationally entrenched cognitive and linguistic processes. Thus, nomological validity would be demonstrated here if the measure of CI was positively and significantly correlated with CSR. We adopted Carroll's (1999) definition of CSR, which asserts that socially responsible organizations fulfil their social responsibilities through legal, economic, discretionary and ethical actions. Based on this definition, Maignan et al. (1999) designed an instrumental scale for measuring CSR in 16 items representing four dimensions; their framework empirically reflects the comprehensiveness of Carroll's perennial model.

Our outcome variable, CSR, was tackled using the item parcelling procedure (Bandalos and Finney, 2001). Following the theoretical development of CSR (Carroll, 1999; Maignan et al., 1999), a partial aggregation procedure was conducted whereby items were parcelled (by averaging) to represent each indicator of CSR respectively (Bagozzi and Heatherton, 1994). This procedure combined the 16 items measuring four dimensions, coded as ECR 
(economic), LGR (legal), ETHR (ethical) and DCSR (discretionary) responsibilities, represented by the latent construct, CSR.

This technique reduced the number of variables, and hence the model's degree of freedom was kept reasonable. With our objective of developing a CI construct, we used the full total disaggregation method for CI, where all parameters were freely estimated, and the partial aggregation method (the summation of each construct's items) for robust results. The technique particularly favors a small sample size, as in the present study, where more a stable parameter estimation can be achieved, and preserves the idea of a single underlying factor; here, the CSR construct (Bagozzi and Heatherton, 1994). In addition to reducing random errors, the technique simplifies complex modelling and yet maintains the concept of multiple indicator measurement (Garver and Mentzer, 1999).

Following the above measurement model procedure, Step 2 was performed and the full model yielded a good fit: $\left(\chi^{2}[293]=395.33, \mathrm{p}<.01 ; \chi^{2} / \mathrm{df}=1.34 ; \mathrm{GFI}=.81 ; \mathrm{IFI}=.95 ; \mathrm{TLI}=\right.$ $.94 ; \mathrm{CFI}=.95 ; \mathrm{RMSEA}=.05)$. The nomological validity result showed $\beta=.77 ; p<.01$, indicating that $\mathrm{CI}$ predicts a significant positive influence on the outcome variable. The final full model results are illustrated in Figure 3.

\section{Insert Figure 3 here}

\section{Discussion}

This paper, reporting the development and validation of a measure of CI, records a novel conceptualization of CI elements that results in a better understanding of the concept from a multidisciplinary perspective, providing much-needed theoretical clarification of CI's key dimensions.

The first dimension, consistent image, reflects communications and visual identity, capturing all the written, spoken and/or graphic design components of a company's selfpresentation that affect corporate image; this brings about an overarching function across 
many items from symbolism to consistent marketing image. It links with the view that CI concerns all possible forms of communication (e.g. marketing, internal and external corporate communication) (Van Riel, 1995) and high levels of symbolism (Carter, 1982). This is conveyed by four items: "Much of our marketing communication helps project a specific image", "The company slogan communicates what the company stands for", "The font we use is important for our look", and "New personnel are always taught that corporate visual identity is important". This is consistent with the literature that emphasizes the role of visual and graphic design in helping an organization increase marketplace recognition and attain visibility and distinguishability by identifying itself to its stakeholders (Van den Bosch et al., 2006).

Furthermore, the item "Staff in our organization observe the corporate visual identity rules" conveys the key role of employees and staff in transmitting brand message, thus encapsulating marketing and corporate communications (via corporate symbol diffusion). This dimension links with branding research through symbolism and consistent image, as conveyed by four items: "Our organization can easily be identified by its corporate visual identity" and "In our organization, it is important to maintain corporate visual identity". The few empirical studies offering insights on this level also advocate consistent CI expression (e.g. Melewar and Saunders, 2000; Simões et al., 2005; Van den Bosch et al., 2006).

The second and third dimensions reflect, for the first time, top management behavioral leadership and employee identification as fundamental dimensions of CI. Top management behavioral leadership assess executives as symbolic leaders. The second dimension shows how far top management engages regularly by action and speech in representational leadership (Van Riel, 1995; Hatch and Schultz, 1997; Balmer, 2017). For example, items such as "Our CEO/head [...] acts as the spokesperson of the organization" and "Our $\mathrm{CEO} /$ head $[\ldots]$ publicizes the activities of the organization" show the importance of top 
managers in expressing central ideas to staff and the public by communication and behavior.

Validating top management behavioral leadership endorses the interview analysis and confirms behavioral leadership as a valid theoretical underpinning for this element of CI, which is considered a novel contribution of the present study. Through empirical analysis, it supports the work of CI scholars (e.g. Scott and Lane, 2000; Melewar, 2003; Vallaster and De Chernatony, 2006; Balmer, 2017), who conceptually address this function of top management.

The findings also reveal the significance of employee behavior to the CI construct. The third dimension captures both the cognitive and affective components of organizational identification, such as "I am sufficiently acknowledged in my company" and "I experience a strong sense of belonging to my company". Validating the employee behavior sub-dimension with organizational identification-related content thus reinforces the view that employee behavior, which directly affects CI and image (see Balmer's premise, 2017), stems from organizational identification, as Van Riel and Fombrun (2007) postulated. Employee identification increases the significance of human resource initiatives in building CI; this demonstrates the need to establish strong cross-functional links between marketing and human resources. Importantly, this finding empirically supports the assumed relationship between $\mathrm{CI}$ and organizational identity, where the first forms the second. However, this position contests the two other views of the juxtaposition of CI and organizational identity: both the theory of overlap and the theory that they are unrelated (Balmer, 2001).

The fourth dimension, mission and values dissemination, is strategic in perspective, supporting the significance of strategy in CI (Balmer, 2017; Simões and Sebastiani, 2017) and corroborating Simões et al. (2005). The rationale is that CI is strategically driven by each organization's unique corporate philosophy, and is reflected in its mission, values and goals: this key dimension internally ddifusses a company's sense of purpose and individuality, 
strengthening the commitment to organizational goals. Cohesiveness across a business unit is conveyed by three items: "There is an agreement on our mission across business levels and units", "Organization's values and mission are regularly communicated to employees", and "Senior management shares the corporate mission with employees". This basis for developing consistent behaviors among employees indicates the task of conveying the right business messages and shows that managers disseminating information can engage in CI development and management.

The fifth scale dimension, founder transformational leadership, reflects the fundamental value-based role of transformational leadership in CI, consistent with researchers who recurrently invoke founders in conceptual/theoretical discussions of CI definitions and expression (Melewar and Karaosmanoglu, 2006; Balmer, 2017). They justify the founding phase as crucial for identity formation: inevitably, founders form companies in their own image (Burmann and Zeplin, 2005; Kitchen et al., 2013), which then becomes essential for company identity. This dimension captures founders' transformational leadership and influence on CI through factors such as their response to crises, behavior as role models, and formal and informal rewards and recognition. Four items encapsulate this: "The approach our organization founder used to help employees to develop their strengths continues to be an important part of who we are", "The approach our organization founder used to generate respect continues to be an important part of who we are", "The approach our organization founder used to suggest ways to get at the heart of complex problems continues to be an important part of who we are", and "The approach our organization founder used to encourage employees to rethink their ideas continues to be an important part of who we are".

The CI literature does not identify transformational leadership as a dimension of CI; however, in line with the leadership literature, the exploratory research findings and the corporate branding literature (Burmann and Zeplin, 2005; Hillestad et al., 2010) the study 
used Bass's (1990) instrument of transformational leadership to measure organization founders as an element of CI, validating it through confirmatory analysis. Notably, we adapted the items to measure the continuing role of founders, whose principles might prevail notwithstanding the founders' absence. Founder transformational leadership implies that aligning marketing and leadership literature is essential, reinforcing our multidisciplinary approach.

\section{Theoretical and managerial implications}

The study makes several theoretical contributions. Through empirical research, it develops and validates a CI scale in the UK's food and beverage industry. Unprecedentedly, this scale conforms to a second-order factor model that ties CI to five first-order dimensions whose eclectic range of disciplines highlights the extensive theoretical roots of CI, which calls for multidisciplinary treatment. Edwards and Bagozzi, (2000) summarize this as "theoretical utility"; i.e. that a theory requires general constructs consisting of specific dimensions or facets. High-order constructs have proven to be successful in increasing theoretical parsimony and reducing model complexity (MacKenzie et al., 2005; Wetzels et al., 2009). Furthermore, the scale can be applied to assess the construct's holistic influence on a range of endogenous variables, such as corporate image, reputation and financial performance, thus encouraging subsequent theoretical development in marketing and related fields.

This study is the first to attempt to integrate marketing communications with visual/graphic design, organisational identification and leadership. It is also the first to empirically assess:

(1) the representational role of management behavior, focused on the ways directors act as spokespersons and are part-and-parcel of public affairs and PR activities;

(2) employee behavior in terms of organizational identification - thus untangling to a degree the internal and external organisational aspects and bridging the schism between the 
OI and CI literature streams; and

(3) the transformational leadership role of the organization founder. Articulating theories that support CI dimensions augments the CI literature, which was formerly dominated by theoretical metaphors and paradigms, and moves CI research onto an empirical plane, based on clearly specified theoretical underpinnings and empirical evidence, as Cornelissen et al. (2012) recommended.

The findings also offer important managerial implications. The CI scale provides a varied range of activities for managers embarking on a CI-building/revising programme. For example, managers could use the scale in relation to CVI, levels of employee identification, mission dissemination and appropriate leadership styles; and could adapt the scale when assessing CI effectiveness, an ongoing strategic requirement (Balmer, 2017). As a diagnostic tool, it can be used for several levels of analysis. CI can now be assessed at both second- and first-order levels (Coleman et al., 2011). Conducting analysis at these different levels would enable managers to concentrate resources on improving particular aspects of CI. Thus, a strategic objective may be to use the scale to investigate current $\mathrm{CI}$ profile and form an objective foundation for change, which is important to academic commentators (i.e. Abratt and Mingione, 2017; Balmer, 2017). Periodically measuring CI could increase its strength and consistency among internal and external stakeholders; this is important since "neglecting identity attributes may result in multiple identity weaknesses perhaps undetected and [hence] perilous" (Balmer, 2017: 21).

\section{Limitations and future research}

The limitations of this study suggest areas for further research. Although the findings can be transferred to other contexts with similar features, caution should be taken when generalizing. Further research is required to test the applicability of the scale internationally or across different industries. Future research could extend the CI framework to explore the 
role of corporate culture or its history in developing CI. In addition, research could assess the construct's influence on other marketing or financial areas, for example reputation and performance. Further research is also needed to empirically examine the relationship between CI dimensions, revealing potential mediating effects. Despite the considerable theoretical support found for the correlation between the dimensions of CI, their interrelationship has not been tested in the same study. The effect of corporate size and brand structure could also be examined.

This study focuses on CI from a managerial perspective. Since companies are not only influenced by managerial actions but shaped also by social, economic and cultural conditions, further research could investigate CI from different stakeholders' perspectives; comparing the views of audiences, for example, and of managers; noting discrepancies/overlaps between CI and perceived image. This is of course currently relevant via organisational interactions in social media. Future studies could facilitate further understanding of the role of word-ofmouth and eWOM relative to $\mathrm{CI}$ management. It would also be enlightening to investigate CI's long-term and dynamic effects, employing longitudinal analysis, which may provide useful information on managerial strategy development and more insights into causation.

\section{References}

Abratt, R. (1989). A new approach to the corporate image management process. Journal of Marketing Management, 5(1), 63-76.

Abratt, R., \& Mingione, M. (2017), Corporate identity, strategy and change. Journal of Brand Management, 24(2), 129-139.

Albert, S., \& Whetten, D. A. (1985). Organizational identity. Research in Organizational Behavior, 7, 263-295.

Alessandri, S. (2001). Modeling corporate identity: a concept explication and theoretical explanation. Corporate Communications: An International Journal, 6(4), 173-182.

Anderson, J. C., \& Gerbing, D. W. (1988). Structural equation modeling in practice: A review and recommended two-step approach. Psychological bulletin, 103(3), 411-423. 
Bagozzi, R. P., \& Heatherton, T. F. (1994). A general approach to representing multifaceted personality constructs: Application to state self-esteem. Structural Equation Modeling: A Multidisciplinary Journal, 1(1), 35-67.

Balmer, J. M. (1995). Corporate identity: the power and the paradox. Design Management Review, 6(1), 39-44.

Balmer, J. M. (1998). Corporate identity and the advent of corporate marketing. Journal of Marketing Management, 14(8), 963-996.

Balmer, J. M. (2001). Corporate identity, corporate branding and corporate marketing Seeing through the fog. European Journal of Marketing, 35(3/4), 248-291.

Balmer, J. M. (2017). Advances in corporate brand, corporate heritage, corporate identity and corporate marketing scholarship. European Journal of Marketing, 51(9/10), 1462-1471.

Balmer, J. M., \& Soenen, G. B. (1997). Operationalising the concept of corporate identity: Articulating the corporate identity mix and the corporate identity management mix. Department of Marketing, University of Strathclyde.

Balmer, J. M., \& Soenen, G. B. (1999). The acid test of corporate identity management. Journal of Marketing Management, 15(1-3), 69-92.

Bandalos, D. L, \&. Finney, S. J. (2001). Item parceling issues in structural equation modeling. In G. A. Marcoulides \& R.E. Schumacker (Eds.). New developments and techniques in structural equation modeling (269-296). New York: Lawrence Erlbaum Associates.

Bass, B. M. (1990). From transactional to transformational leadership: Learning to share the vision. Organizational Dynamics, 18(3), 19-31.

Basu, K., \& Palazzo, G. (2008). Corporate social responsibility: A process model of sensemaking. Academy of Management Review, 33(1), 122-136.

Bernstein, D. (1984). Company image and reality: A critique of corporate communications. Eastbourne: Rinehart \& Winston Ltd.

Boroş, S. (2008). Organizational identification: Theoretical and empirical analyzes of competing conceptualizations. Cognitie, Creier, Comportament/Cognition, Brain, Behavior, 12(1), 1-27.

Bravo, R., Matute, J., \& Pina, J. M. (2016). Corporate identity management in the banking sector: effects on employees' identification, identity attractiveness, and job satisfaction. Service Business, 10(4), 687-714.

Brexendorf, T. O., \& Kernstock, J. (2007). Corporate behavior vs brand behavior: Towards an integrated view? Journal of Brand Management, 15(1), 32-40. 
Byrne, B. M. (2001). Structural equation modeling: Perspectives on the present and the future. International Journal of Testing, 1(3-4), 327-334.

Burmann, C., \& Zeplin, S. (2005). Building brand commitment: A behavioral approach to internal brand management. Journal of Brand Management, 12(4), 279-300.

Carroll, A. B. (1999). Corporate social responsibility: Evolution of a definitional construct. Business \& Society, 38(3), 268-295.

Carter, D. E. (1982). Designing corporate identity programs for small corporations. New York: Art Direction Book Company.

Christensen, L. J., Mackey, A., \& Whetten, D. (2014). Taking responsibility for corporate social responsibility: The role of leaders in creating, implementing, sustaining, or avoiding socially responsible firm behaviors. The Academy of Management Perspectives, 28(2), 164-178.

Churchill Jr, G. A. (1979). A paradigm for developing better measures of marketing constructs. Journal of Marketing Research, 16(1), 64-73.

Clark, S. M., Gioia, D. A., Ketchen Jr, D. J., \& Thomas, J. B. (2010). Transitional identity as a facilitator of organizational identity change during a merger. Administrative Science Quarterly, 55(3), 397-438.

Coleman, D., de Chernatony, L., \& Christodoulides, G. (2011). B2B service brand identity: Scale development and validation. Industrial Marketing Management, 40(7), 1063-1071.

Conte, F., Siano, A., \& Vollero, A. (2017). CEO communication: engagement, longevity and founder centrality: An exploratory study in Italy. Corporate Communications: An International Journal, 22(3), 273-291.

Conway, J. M., \& Huffcutt, A. I. (2003). A review and evaluation of exploratory factor analysis practices in organizational research. Organizational research methods, 6(2), $147-168$.

Cornelissen, J., Christensen, L., \& Kinuthia, K. (2012). Corporate brands and identity: Developing stronger theory and a call for shifting the debate. European Journal of Marketing, 46(7/8), 1093-1102.

Cornelissen, J. P., \& Elving, W. J. (2003). Managing corporate identity: an integrative framework of dimensions and determinants. Corporate Communications: An International Journal, 8(2), 114-120.

Cycyota, C. S., \& Harrison, D. A. (2006). What (not) to expect when surveying executives: A meta-analysis of top manager response rates and techniques over time. Organizational Research Methods, 9(2), 133-160. 
David, P., Kline, S., \& Dai, Y. (2005). Corporate social responsibility practices, corporate identity, and purchase intention: A dual-process model. Journal of Public Relations Research, 17(3), 291-313.

DeVellis, R. F. (1991). Scale Development: Theory and Applications. CA: Sage.

Dowling, G. (2001), Creating Corporate Reputations. Oxford: Oxford University Press.

Edwards, J. R., \& Bagozzi, R. P. (2000). On the nature and direction of relationships between constructs and measures. Psychological Methods, 5(2), 155.

European Commission (2005). The New SME Definition: User Guide and Model Declaration. Enterprise and Industry Publications.

Food and Drink Federation (2017). Our Industry in Pictures. Value of Food \& Drink Retrieved from https://www.fdf.org.uk/publicgeneral/stats-2017.pdf

Field, A. (2009). Discovering Statistics Using SPSS. London: Sage.

Fornell, C., \& Larcker, D. F. (1981). Evaluating structural equation models with unobservable variables and measurement error. Journal of Marketing Research, 18(1), 39-50.

Foroudi, P., Melewar, T. C., \& Gupta, S. (2014). Linking corporate logo, corporate image, and reputation: An examination of consumer perceptions in the financial setting. Journal of Business Research, 67(11), 2269-2281.

Gambetti, R.C., Melewar, T.C., \& Martin, K.D. (2017). Guest Editors' Introduction: Ethical Management of Intangible Assets in Contemporary Organizations. Business Ethics Quarterly, 27(3), 381-392.

Garver, M. S., \& Mentzer, J. T. (1999). Logistics research methods: employing structural equation modeling to test for construct validity. Journal of Business Logistics, 20(1), 3357.

Gray, E., and Balmer, J. (1998). Managing corporate image and corporate reputation. Long Range Planning, 31(5), 695-702.

Hair, J. F., Black, W. C., Babin, B. J., \& Anderson, R. E. (2010). Multivariate Data Analysis. NJ: Prentice Hall.

Hamid, M. A., Ab Rahman, N. M. N., \& Nor, N. M. (2012). Leadership behavior and performance: A case study of Takaful representatives in Malaysia. African Journal of Business Management, 6(6), 2291.

Hatch, M., \& Schultz, M. (1997). Relations between organizational culture, identity and image. European Journal of Marketing, 31(5/6), 356-365. 
He, H. (2012). Corporate identity anchors: a managerial cognition perspective. European Journal of Marketing, 46(5), 609-625.

Hill, C. W., \& Jones, T. M. (1992). Stakeholder-agency theory. Journal of Management Studies, 29(2), 131-154.

Hillestad, T., Xie, C., \& Haugland, S. A. (2010). Innovative corporate social responsibility: the founder's role in creating a trustworthy corporate brand through "green innovation". Journal of Product \& Brand Management, 19(6), 440-451.

Institute for Manufacturing [IfM] (2010). Value of Food \& Drink Manufacturing to the UK. Retrieved from https://www.ifm.eng.cam.ac.uk/uploads/Resources/Reports/100705 food_drink.pdf

Kitchen, P. J., Tourky, M. E., Dean, D., \& Shaalan, A. S. (2013). Corporate identity Antecedents and components: Toward a theoretical framework. Corporate Reputation Review, 16(4), 263-284.

Kline, R. (1998). Principles and practice of structural equation modelling. New York: The Guildford Press.

Lloria, M. B., \& Moreno-Luzon, M. D. (2014). Organizational learning: Proposal of an integrative scale and research instrument. Journal of Business Research, 67(5), 692-697.

MacKenzie, S. B., Podsakoff, P. M., \& Jarvis, C. B. (2005). The problem of measurement model misspecification in behavioral and organizational research and some recommended solutions. Journal of Applied Psychology, 90(4), 710.

Maignan, I., Ferrell, O. C., \& Hult, G. T. M. (1999). Corporate citizenship: Cultural antecedents and business benefits. Journal of the Academy of Marketing Science, 27(4), 455-469.

Melewar, T. C. (2003). Determinants of the corporate identity construct: a review of the literature. Journal of Marketing Communications, 9(4), 195-220.

Melewar, T. C., Foroudi, P., Dinnie, K., \& Nguyen, B. (2018). The role of corporate identity management in the higher education sector: an exploratory case study. Journal of Marketing Communications, 24(4), 337-359.

Melewar, T. C., \& Jenkins, E. (2002). Defining the corporate identity construct. Corporate Reputation Review, 5(1), 76-90.

Melewar, T. C., \& Karaosmanoglu, E. (2006). Seven dimensions of corporate identity: A categorisation from the practitioners' perspectives. European Journal of Marketing, 40(7/8), 846-869. 
Melewar, T. C., Karaosmanoglu, E., \& Paterson, D. (2005). Corporate identity: concept, components and contribution. Journal of General Management, 31(1), 59-81.

Melewar, T. C., \& Saunders, J. (2000). Global corporate visual identity systems: using an extended marketing mix. European Journal of Marketing, 34(5/6), 538-550.

Moingeon, B., \& Ramanantsoa, B. (1997). Understanding corporate identity: the French school of thought. European Journal of Marketing, 31(5/6), 383-395.

Nunnally, J. (1978). Psychometric Theory. New York: McGraw Hill.

Olins, W. (1995). The New Guide to Identity: How to Create and Sustain Change through Managing Identity. Aldershot: Gower.

Powell, S. M. (2011). The nexus between ethical corporate marketing, ethical corporate identity and corporate social responsibility: An internal organizational perspective. European Journal of Marketing, 45(9/10), 1365-1379.

Punjaisri, K., Evanschitzky, H., \& Wilson, A. (2009). Internal branding: an enabler of employees' brand-supporting behaviours. Journal of Service Management, 20(2), 209226.

Riketta, M. (2005). Organizational identification: A meta-analysis. Journal of Vocational Behavior, 66(2), 358-384.

Schmeltz, L. (2014). Identical or just compatible? The utility of corporate identity values in communicating corporate social responsibility. International Journal of Business Communication, 51(3), 234-258.

Scott, S. G., \& Lane, V. R. (2000). A stakeholder approach to organizational identity. Academy of Management Review, 25(1), 43-62.

Shamir, B., House, R. J., \& Arthur, M. B. (1993). The motivational effects of charismatic leadership: A self-concept based theory. Organization Science, 4(4), 577-594.

Simões, C., Dibb, S., \& Fisk, R. P. (2005). Managing corporate identity: an internal perspective. Journal of the Academy of Marketing Science, 33(2), 153-168.

Simões, C., \& Sebastiani, R. (2017). The nature of the relationship between corporate identity and corporate sustainability: Evidence from the retail industry. Business Ethics Quarterly, 27(3), 423-453.

Smidts, A., Pruyn, A. T. H., \& Van Riel, C. B. (2001). The impact of employee communication and perceived external prestige on organizational identification. Academy of Management Journal, 44(5), 1051-1062. 
Stogdill, R. M. (1963). Manual for the leader behavior description questionnaire-Form XII: An experimental revision. Bureau of Business Research, College of Commerce and Administration, Ohio State University.

Stuart, H. (1999). Towards a definitive model of the corporate identity management process. Corporate Communications: An International Journal, 4(4), 200-207.

Suddaby, R. (Ed.). (2010). Editor's comments: Construct clarity in theories of management and organization.

Tourky, M., Kitchen, P., \& Shaalan, A. (2019). The role of corporate identity in CSR implementation: An integrative framework. Journal of Business Research. DOI 10.1016/j.jbusres.2019.02.046

Vallaster, C., \& de Chernatony, L. (2006). Internal brand building and structuration: the role of leadership. European Journal of Marketing, 40(7/8), 761-784.

Van den Bosch, A. L., Elving, W. J., \& de Jong, M. D. (2006). The impact of organizational characteristics on corporate visual identity. European Journal of Marketing, 40(7/8), 870-885.

Van Rekom, J. (1997). Deriving an operational measure of corporate identity. European Journal of Marketing, 31(5/6), 410-422.

Van Riel, C.B.M. (1995). Principles of Corporate Communications. London: Prentice Hall.

Van Riel, C. B., \& Balmer, J. M. (1997). Corporate identity: the concept, its measurement and management. European Journal of Marketing, 31(5/6), 340-355

Van Riel, C. B., \& Fombrun, C. J. (2007). Essentials of Corporate Communication: Implementing Practices for Effective Reputation Management. Oxon: Routledge.

Wetzels, M., Odekerken-Schröder, G., \& Van Oppen, C. (2009). Using PLS path modeling for assessing hierarchical construct models: Guidelines and empirical illustration. MIS Quarterly, 3(1), 177-195.

Wolfinbarger, M., \& Gilly, M. C. (2003). eTailQ: dimensionalizing, measuring and predicting etail quality. Journal of Retailing, 79(3), 183-198.

Zaichkowsky, J. L. (1985). Measuring the involvement construct. Journal of Consumer Research, 12(3), 341-352. 
Table 1: Sources of CI scale items

\begin{tabular}{|c|c|c|}
\hline Dimension & Measurement focus & Items adapted from \\
\hline Communication & $\begin{array}{l}\text { Breadth and coherence among media and } \\
\text { messages }\end{array}$ & $\begin{array}{l}\text { Van Riel and Fombrun } \\
\text { (2007); Simões et al. (2005) }\end{array}$ \\
\hline $\begin{array}{l}\text { Corporate visual } \\
\text { identity }\end{array}$ & $\begin{array}{l}\text { Functionality and consistency of corporate } \\
\text { visual identity system and its applications }\end{array}$ & $\begin{array}{l}\text { Van den Bosch et al. } \\
\text { (2006); Melewar and } \\
\text { Saunders (2000) }\end{array}$ \\
\hline $\begin{array}{l}\text { Top management } \\
\text { behavioral } \\
\text { leadership }\end{array}$ & $\begin{array}{l}\text { Degree to which top managers act as } \\
\text { representational leaders for their } \\
\text { organizations }\end{array}$ & $\begin{array}{l}\text { Abdul Hamid et al. (2012); } \\
\text { Benson (1998); } \\
\text { Stogdill (1963) }\end{array}$ \\
\hline $\begin{array}{l}\text { Employee } \\
\text { identification }\end{array}$ & $\begin{array}{l}\text { Extent to which members of staff define } \\
\text { themselves by the same attributes as those } \\
\text { they believe define the organization }\end{array}$ & $\begin{array}{l}\text { Smidts et al. (2001); Hatch } \\
\text { and Schultz (1997); Van } \\
\text { Riel and Fombrun (2007) }\end{array}$ \\
\hline $\begin{array}{l}\text { Mission and values } \\
\text { dissemination }\end{array}$ & $\begin{array}{l}\text { Degree to which mission and values are } \\
\text { disseminated }\end{array}$ & Simões et al. (2005) \\
\hline $\begin{array}{l}\text { Founder } \\
\text { transformational } \\
\text { leadership }\end{array}$ & $\begin{array}{l}\text { Degree to which (value-based) founders } \\
\text { provide meaning and stimulate followers }\end{array}$ & $\begin{array}{l}\text { Bass (1990); } \\
\text { Shamir et al. (1993) }\end{array}$ \\
\hline
\end{tabular}


Table 2: EFA factor loadings, eigenvalues and variance extracted

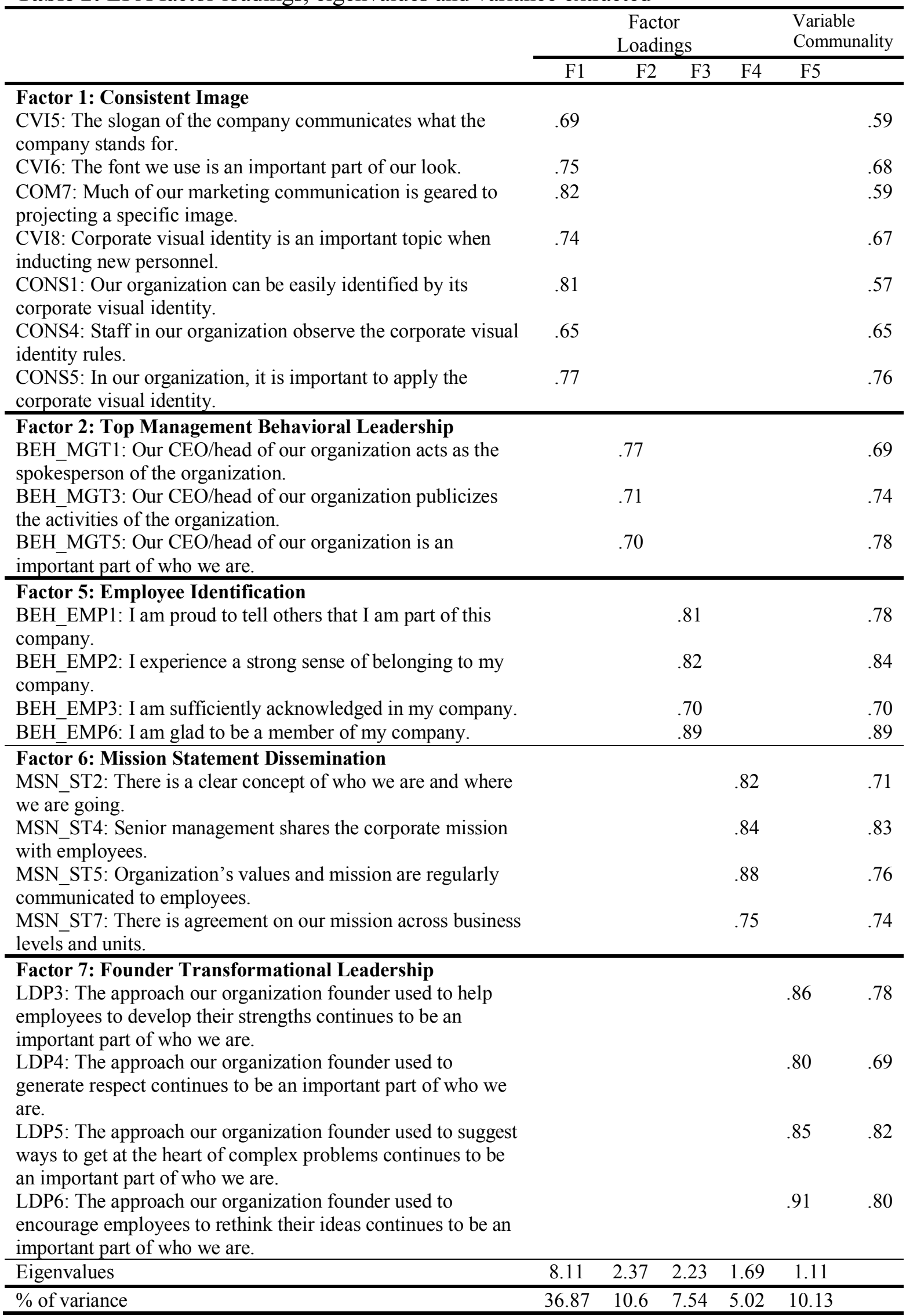


Table 3: First Order and Second Order Results: CFA loadings, and structural relationship

\begin{tabular}{|c|c|c|}
\hline & $\begin{array}{c}\text { CFA } \\
\text { First Order } \\
\text { Item } \\
\text { Loadings }\end{array}$ & $\begin{array}{c}\text { CFA } \\
\text { Second Order } \\
\text { Structural } \\
\text { Relationships } \\
\end{array}$ \\
\hline Factor 1: Consistent Image & & .60 \\
\hline $\begin{array}{l}\text { CVI5: The slogan of the company communicates what the company } \\
\text { stands for. }\end{array}$ & .68 & \\
\hline CVI6: The font we use is an important part of our look. & .71 & \\
\hline $\begin{array}{l}\text { COM7: Much of our marketing communication is geared to projecting a } \\
\text { specific image. }\end{array}$ & .79 & \\
\hline $\begin{array}{l}\text { CVI8: Corporate visual identity is an important topic when inducting } \\
\text { new personnel. }\end{array}$ & .69 & \\
\hline $\begin{array}{l}\text { CONS1: Our organization can be easily identified by its corporate visual } \\
\text { identity. }\end{array}$ & .75 & \\
\hline $\begin{array}{l}\text { CONS4: Staff in our organization observe the corporate visual identity } \\
\text { rules. }\end{array}$ & .68 & \\
\hline $\begin{array}{l}\text { CONS5: In our organization, it is important to apply the corporate visual } \\
\text { identity. }\end{array}$ & .75 & \\
\hline Factor 2: Top Management Behavioral Leadership & & .79 \\
\hline $\begin{array}{l}\text { BEH_MGT1: Our CEO/head of our organization acts as the } \\
\text { spokesperson of the organization. }\end{array}$ & .80 & \\
\hline $\begin{array}{l}\text { BEH_MGT3: Our CEO/head of our organization publicizes the } \\
\text { activities of the organization. }\end{array}$ & .68 & \\
\hline $\begin{array}{l}\text { BEH_MGT5: Our CEO/head of our organization is an important part of } \\
\text { who we are. }\end{array}$ & .64 & \\
\hline Factor 5: Employee Identification & & .77 \\
\hline BEH_EMP1: I am proud to tell others that I am part of this company. & .86 & \\
\hline BEH_EMP2: I experience a strong sense of belonging to my company. & .89 & \\
\hline BEH_EMP3: I am sufficiently acknowledged in my company. & .76 & \\
\hline BEH_EMP6: I am glad to be a member of my company. & .94 & \\
\hline Factor 6: Mission Statement Dissemination & & .67 \\
\hline $\begin{array}{l}\text { MSN_ST2: There is a clear concept of who we are and where we are } \\
\text { going. }\end{array}$ & .66 & \\
\hline $\begin{array}{l}\text { MSN_ST4: Senior management shares the corporate mission with } \\
\text { employees. }\end{array}$ & .79 & \\
\hline $\begin{array}{l}\text { MSN_ST5: Organization's values and mission are regularly } \\
\text { communicated to employees. }\end{array}$ & .89 & \\
\hline $\begin{array}{l}\text { MSN_ST7: There is an agreement on our mission across business levels } \\
\text { and units. }\end{array}$ & .90 & \\
\hline Factor 7: Founder Transformational Leadership & & .67 \\
\hline $\begin{array}{l}\text { LDP3: The approach our organization founder used to help employees to } \\
\text { develop their strengths continues to be an important part of who we are. }\end{array}$ & .84 & \\
\hline $\begin{array}{l}\text { LDP4: The approach our organization founder used to generate respect } \\
\text { continues to be an important part of who we are. }\end{array}$ & .74 & \\
\hline $\begin{array}{l}\text { LDP5: The approach our organization founder used to suggest ways to } \\
\text { get at the heart of complex problems continues to be an important part of } \\
\text { who we are. }\end{array}$ & .84 & \\
\hline $\begin{array}{l}\text { LDP6: The approach our organization founder used to encourage } \\
\text { employees to rethink their ideas continues to be an important part of } \\
\text { who we are. }\end{array}$ & .88 & \\
\hline
\end{tabular}

Note: All parameters were significant at $\mathrm{p}<.01$;

$\mathrm{CI}=$ consistent image $\mathrm{TMBL}=$ top management behavioral leadership, $\mathrm{EI}=$ employee identification, $\mathrm{MVD}=$ mission and values dissemination, $\mathrm{FTL}=$ founder transformational leadership 
Table 4: Descriptive statistics, correlations, reliability and validity estimates

\begin{tabular}{|c|c|c|c|c|c|c|c|c|c|c|}
\hline & Mean & S.D. & 1 & 2 & 3 & 4 & 5 & 6 & $\begin{array}{l}\text { Composite } \\
\text { Reliability } \\
\quad \text { (CR) }\end{array}$ & $\begin{array}{l}\text { Average } \\
\text { Variance } \\
\text { Extracted } \\
\text { (AVE) }\end{array}$ \\
\hline 1. CI & 3.68 & .79 & .86 & & & & & & .88 & .52 \\
\hline 2. TMBL & 3.99 & .86 & $.39 * *$ & .81 & & & & & .83 & .60 \\
\hline 3. EI & 4.30 & .70 & $.39 * *$ & $.33 * *$ & .91 & & & & .92 & .74 \\
\hline 4. MVD & 3.58 &. .88 & $.45^{* *}$ & $.39 * *$ & $.62 * *$ & .88 & & & .87 & .62 \\
\hline 5. FTL & 3.42 & .86 & $.33 * *$ & $.38 * *$ & $.48 * *$ & $.41 * *$ & .89 & & .89 & .67 \\
\hline 6. CSR & 4.05 & .52 & $.43 * *$ & $.30 * *$ & $.31 * *$ & $.42 * *$ & $.44 * *$ & .84 & .84 & .58 \\
\hline \multicolumn{11}{|c|}{$\begin{array}{l}\text { Note: } * * \text { Correlation is significant at the } 0.01 \text { level ( } 2 \text {-tailed); Cronbach's alpha coefficients are shown } \\
\text { italics along the diagonal. } \\
\mathrm{CI}=\text { consistent image, TMBL = top management behavioral leadership, EI = employee identification, } \\
\text { MVD = mission and values eissemination, FTL = founder transformational leadership, } \\
\text { CSR = corporate social responsibility }\end{array}$} \\
\hline
\end{tabular}




\begin{tabular}{|c|c|}
\hline $\begin{array}{l}\text { Specify domain of } \\
\text { CI construct }\end{array}$ & $\begin{array}{l}\text { Aim: Content Validity } \\
\text { Sources: Literature search, in-depth interviews }\end{array}$ \\
\hline Generate Pool of Items & $\begin{array}{l}\text { Aim: Content and Face Validity } \\
\text { Sources: Literature, Exploratory interviews } \\
\text { Outcome: Initial list of } 85 \text { items of CI that captured the conceptual } \\
\text { domains of the six dimensions }\end{array}$ \\
\hline Experience Survey & $\begin{array}{l}\text { Aim: Content and Face Validity/ eliminate any ambiguous, redundantor } \\
\text { faulty items } \\
\text { Initial feedback by } 5 \text { academics specialists in marketing and branding } \\
\text { Outcome: list of } 65 \text { items of CI with some reworded items }\end{array}$ \\
\hline Expert Panel & $\begin{array}{l}\text { Aim: Content and Face Validity/ evaluate how far each item represented } \\
\text { the domain of CI and suggest new items } \\
\text { Assessed by three leading brand academics and three senior PR and brand } \\
\text { agency consultants based in the UK } \\
\text { Outcomes: Filtered List of } 53 \text { Items of CI }\end{array}$ \\
\hline Pretest survey & $\begin{array}{l}\text { Aim: Content andFace Validity/ assess respondents' understanding of the } \\
\text { questions } \\
\text { Series of Pretests with } 10 \mathrm{MBA} \text { students working as senior marketing } \\
\text { executives in the food sector } \\
\text { Outcomes: Final version of CI questionnaire of } 29 \text { items }\end{array}$ \\
\hline Pilot study & $\begin{array}{l}\text { Aim: Content and Face Validity } \\
\text { Pilot study with } 10 \text { marketing managers in food companies selected } \\
\text { randomly from the sampling frame } \\
\text { Outcomes: No further changes/ improvements }\end{array}$ \\
\hline Administer final survey & $\begin{array}{l}824 \text { senior marketing executives from Food and Beverage Industry } \\
\text { received the survey. } \\
\text { Outcomes: } 126 \text { completed questionnaires }\end{array}$ \\
\hline Purify scale items & $\begin{array}{l}\text { Aim: Reliability } \\
\text { Cronbach's } \alpha / \text { item to total correlations (using SPSS) }\end{array}$ \\
\hline Exploratory factor analysis & \\
\hline $\begin{array}{l}\text { Confirmatory factor } \\
\text { analysis }\end{array}$ & $\begin{array}{l}\text { Aim: Composite reliability and AVE, discriminant and convergent } \\
\text { validity, item and construct unidimensional } \\
\text { Measurement mode (first and second-order models) (using AMOS) }\end{array}$ \\
\hline $\begin{array}{l}\text { Structural equation } \\
\text { modelling }\end{array}$ & $\begin{array}{l}\text { Aim: Nomological Validity } \\
\text { Using full structural model: Assess influence of CI on CSR } \\
\text { (using AMOS) }\end{array}$ \\
\hline
\end{tabular}

Sources: Adapted from Anderson and Gerbing (1988), Churchill (1979), DeVellis (1991).

Figure 1: CI scale and questionnaire development process 


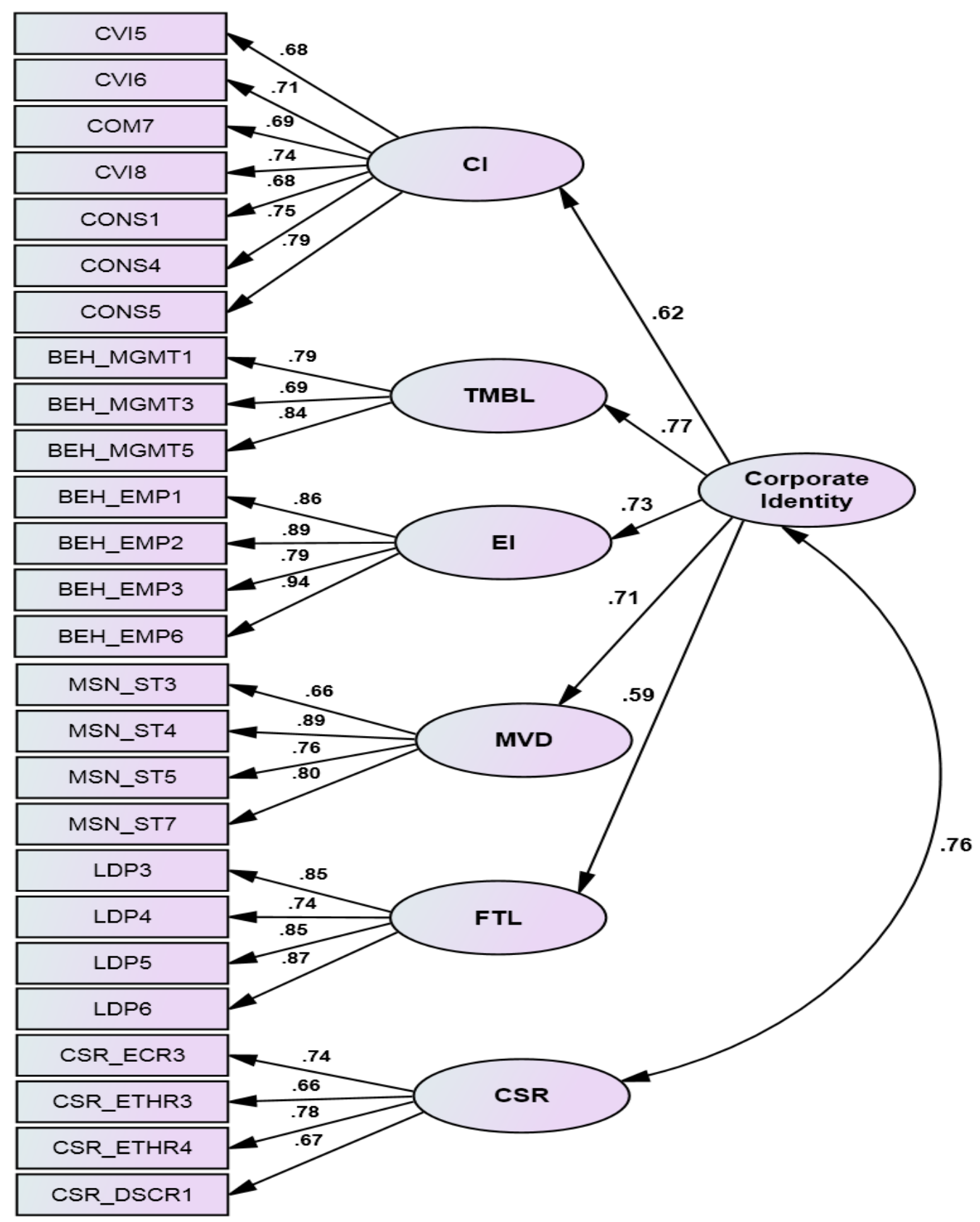

Figure 2: Step 1 - Full measurement model for corporate identity and CSR

Note: All parameters were significant at $\mathrm{p}<.01 . \mathrm{CI}=$ consistent image, $\mathrm{TMBL}=$ top management behavioral leadership, $\mathrm{EI}=$ employee identification, $\mathrm{MVD}=$ mission and values eissemination, $\mathrm{FTL}=$ founder transformational leadership, CSR = corpoate social responsibility. 


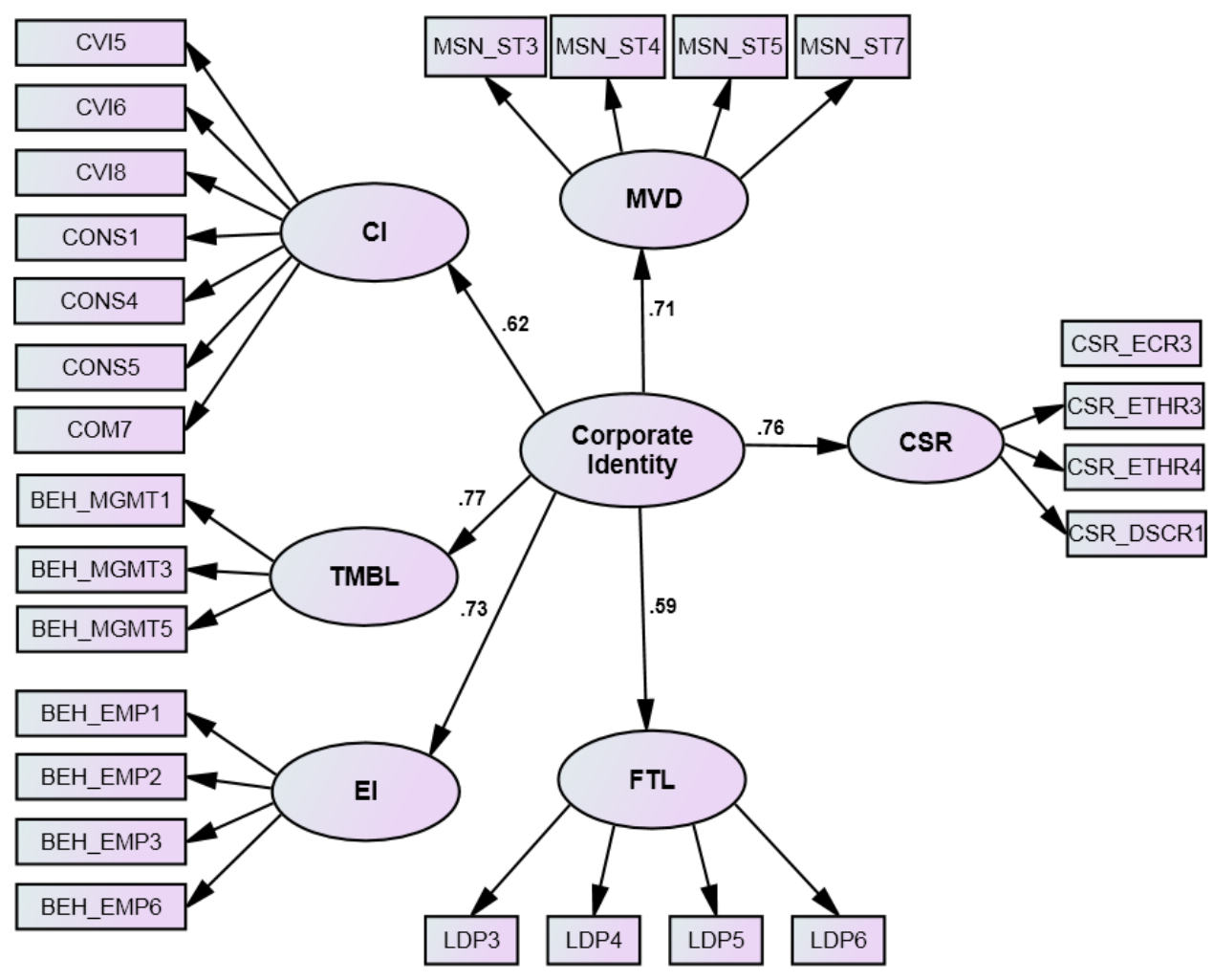

Figure 3: Step 2 - Full structural model for corporate identity and CSR

Note: All parameters were significant at $\mathrm{p}<.01 . \mathrm{CI}=$ consistent image, $\mathrm{TMBL}=$ top management behavioral leadership, $\mathrm{EI}=$ employee identification, $\mathrm{MVD}=$ mission and values dissemination, $\mathrm{FTL}=$ founder transformational leadership, $\mathrm{CSR}=$ corporate social responsibility 
Appendix 1: The meaning and elements of CI: A chronology of key definitions

\begin{tabular}{|c|c|c|}
\hline Authors & Key Aspects & Research Type \\
\hline Carter (1982) & All visual expressions, including logo & Conceptual research \\
\hline Abratt (1989) & Visual expressions; behavior $\backslash$ & Conceptual research \\
\hline $\begin{array}{l}\text { Moingeon and } \\
\text { Ramanantsoa (1997) }\end{array}$ & Corporate personality, culture, internal organizational image & $\begin{array}{l}\text { Qualitative research using interviews with } \\
\text { managers in French enterprises }\end{array}$ \\
\hline Marwick and Fill (1997) & Visual identity; communications; behavior & $\begin{array}{l}\text { Quantitative research using surveys from } \\
\text { three stakeholder groups in organization } \\
\text { operating in the European aerospace } \\
\text { industry in the UK. }\end{array}$ \\
\hline Van Rekom (1997) & Visual; communications; behavior; goals; values & $\begin{array}{l}\text { Qualitative research using means-end } \\
\text { approach to explore organizational identity }\end{array}$ \\
\hline Van Riel (1995) & Visual, communication, behavior & Conceptual research \\
\hline Gray and Balmer (1998) & $\begin{array}{l}\text { Company strategy (company product-market scope, overall objectives, } \\
\text { policies), philosophy (values and beliefs), culture (shared values, beliefs } \\
\text { organization members hold common), and organizational design (degree of } \\
\text { centralisation, size of staff, design of jobs, number of hierarchical levels) }\end{array}$ & Conceptual research \\
\hline $\begin{array}{l}\text { Balmer and Soenen } \\
\text { (1999) }\end{array}$ & $\begin{array}{l}\text { Three main elements/ components: mind (managerial vision, corporate } \\
\text { philosophy, strategy, performance, brand architecture, nature of corporate } \\
\text { ownership, organizational history), soul (distinct values, mix of sub-cultures, } \\
\text { employee affinities, internal images), and voice (uncontrolled communication, } \\
\text { controllable communication, symbolism, employee and corporate behavior, } \\
\text { indirect (external/third-party) communication) }\end{array}$ & $\begin{array}{l}\text { Qualitative research, based on in-depth } \\
\text { interviews in a major international identity } \\
\text { consultancy in London. }\end{array}$ \\
\hline Stuart (1999) & Symbolism (visual identity); communication; behavior & Conceptual research \\
\hline Hatch and Schultz (1997) & Company strategy; philosophy; organizational design; culture & Conceptual research \\
\hline
\end{tabular}


Melewar and Jenkins

(2002)

Cornelissen and Elving

Melewar (2003)

Simões et al. (2005)

Melewar and

Karaosmanoglu (2006)

He (2012)

Nygm et al. (2016)
Four dimensions: communication and visual identity (corporate

communication, uncontrollable communication, architecture and location, and

CVI and its application), behavior (corporate behavior, management behavior and employee behavior), corporate culture (goals, philosophy and principles,

nationality, organizational imaginary and history), and market conditions

(nature of industry and corporate/marketing strategy)

Symbolism (logos, house style), representational forms of behavior (behavior of store employees, sales representatives, receptionists), planned forms of publicity and advertising communications, and thematic and visual consistency across messages carried by these media

Seven dimensions: corporate communication (controlled, uncontrolled, indirect), corporate design (CVI system, application of CVI system), corporate culture (corporate philosophy, values, mission, principles, guidelines, history, founder of the company, country of origin, subculture), behavior (employee, management), corporate structure (brand, organizational structure), industry identity, and corporate strategy (differentiation, positioning strategy)

Three dimensions: mission and values dissemination, consistent image implementation, and visual identity implementation

Six dimensions: Corporate communication (marketing, management, organizational); corporate design (slogan, architecture, location, office layout, website); corporate culture (mission, vision, values); corporate behavior (company, management, employee); corporate structure (brand, organizational); corporate strategy (positioning, differentiation).

Seven anchors: ownership, vision and mission, values and beliefs, business, personality attributes, external image, and strategic performance

Name (meaning and superstition), status (face and respect), organization culture (behavior, mission, and vision), self-expression (beliefs, integrity and persona), Affiliation/network (guanxi), innovation (founder and government), strategy (management, leadership and structure), and visual design (look and website)
Conceptual research

Conceptual research

Conceptual research

Mixed methods research using in-depth interviews followed by surveys in hotel industry in England

Qualitative research using in-depth

interviews with executives and lower level employees from a broad spectrum of industries in the UK

Qualitative research using semi-structured interviews with senior managers from organizations in the British financial service industry

Qualitative research using in-depth interviews with managers from new hightechnology ventures in China 